\title{
Financial Innovation's Opportunities and Challenge in the Tax Policy
}

\author{
Ranlin Zhao \\ Tianjin University of finance and economics, Tianjin 300000, China
}

\begin{abstract}
Since the 1970 s, financial innovation become a phenomenon which is of particular concern in the field of economics finance. Financial innovation not only have a booming developed in the country's financial markets, and play an important role in the international financial market. Not only in terms of financial products, and occur in the financial system, financial technology etc. So brings the huge challenge to tax policy. With the speeding up of the global integration of economic, and more widely used of electronic information technology in the financial field, the tax policy of financial innovation will become an important subject in our country. In this paper, based on the basic theory of the tax policy of financial innovation to do a brief preview and review.
\end{abstract}

Index Terms - financial innovation, tax, policy

\section{Financial Innovation and Tax Policy Relevance Theory Analysis}

Especially the theory of institutional economics and game theory from economics perspective, financial innovation is a consequences of social and economic development to a certain stage and under the condition of financial institutions to obtain maximum income and government regulation system related to each other. Tax in the process of the game, on the one hand as the government's system of financial regulation is an important part of the constraints on financial institutions and financial transactions. On the other hand taxes as part of the financial product transaction costs, itself is one of the causes of financial innovation. Due to the current tax law in practice on the trading behavior of different economic interests, the same trading behavior of different subject rules on the different tax burden, or even the same economic benefits of different way to trade the tax burden, there is also a difference between multiple game between financial innovation and tax financial innovation must make bigger influence on the government's tax policy, the need to make further analysis of the application of the theory of tax.

\section{Financial Innovation to the Impact of the Tax}

Financial innovation to a large extent is a evasion of the existing system, therefore, the avoidance of the current tax theory, policy and collection system and so on each aspect all brings a great impact, specifically, mainly manifested in the following aspects:

\section{(1) The impact of the basic elements of tax}

As is known to all, taxation elements refers to constitute the basic factors of tax categories, including the taxpayer, tax targets and tax rates. With the deepening of financial innovation, the current tax base caused great impact. The income tax, for example: First, causing the uncertainty of the taxpayer. Through financial innovation, the economic benefits can be obtained and the law on the ownership of the separation, and even more difficult to determine taxpayers. Investment fund of property taxes, for example, the current worldwide, whether investment funds as the main tax have different understanding. Second, blurs the levy object. The current practice of taxation will be divided into goods and services tax according to the nature of the object, the income, property, and behavior, and then set the relevant taxes, but financial innovation is making this kind of classification is blurry, so make sure the related tax nature of the financial products become very difficult. The current tax law is generally according to the different sources to distinguish the nature of the income, and implementation of tax rate and tax in different ways, such as can be divided into general income and capital gains, the latter is often even lighter tax exemption. But as a result of financial derivative products of flexible form, complex and changeable, the amount of income is difficult to determine the source of the way and the nature, to the great impact of the tax law. Third, the impact on tax rates. Under the current tax law, the government usually of different source and nature of the income tax according to different tax rates, but financial innovation can through securitisation, to convert a source of income for another source of income, especially the high taxes income into a low tax revenue, it will cause certain impact to the tax policy.

\section{(2)The impact on the principle of tax fairness and efficiency}

Tax fairness is one of the highest tax principles, it refers to have equal tax capacity should be equal tax burden, different taxable capacity shall be different tax burden. Financial innovation products trading range due to the universality, diversity and complexity of the formation, participants in the objective cause both the splitting method is adopted and the whole legal tax treatment, are difficult to reflect the essence of the financial innovation products, make the amount of taxable income in the nature, category, not only on elements such as hard to define, even the taxable income of the home also is difficult to discern, and difficult to achieve the requirement of the tax fair principle.

Tax efficiency principle requires the government tax on the one hand, should not hinder the role economic development, on the other hand to improve the efficiency of tax collection and administration, as much as possible and minimize the collection and administration cost. With the rapid development of financial innovation, which makes the efficiency of tax principle of dilemma in front of financial 
innovation, a great impact on the efficiency of tax principles: on the one hand, different from the traditional financial instruments, financial innovation to make the taxpayer's income and cost, assets and liabilities and other factors is difficult to differentiate clearly, not only affects the reliability in time of tax management, and may cause tax avoidance or tax arbitrage behavior; On the other hand, if carried out in accordance with the collection and management mode of traditional financial products strict collection and administration, and the formation of financial development barriers to the passive situation.

\section{(3)The impact on tax collection and administration}

Financial innovation with the development of information and network technology, more and more use of the advanced science and technology to achieve the purpose of tax avoidance, this will bring greater difficulty of tax collection and administration. As with the maturity of network transactions encryption technology, the taxpayer can through the network, use a variety of ways such as encryption, authorization, hidden trading information, so as to avoid tax obligations. Again, such as between counterparties with different tax rates, taxpayer can often through equity and debt swaps and other derivatives trading to evade, to achieve a certain degree of tax avoidance.

\section{(4) The independence of the impact of a country's tax policy}

Sovereign independent taxation policy is a government the most outstanding reflected, but under the background of economic and financial globalization, due to the global flow characteristics of the tax base of financial products, the independence of the financial innovation to a country's tax policy has brought great impact. The Tobin tax, for example, due to the application of information technology and network technology, makes the transfer of capital in the global range close to the speed of light, a government as a Tobin tax alone, will inevitably greater damage to their own interests, make a government cannot independent of the related tax policy, the independence of the government tax policy also caused the damage.

Above all, as a result of financial innovation challenge and influence on the existing tax policy, make financial and financial tool innovation becomes one of the biggest challenges facing the current taxation theory and policy, need tax theory and practice of studying carefully addressed.

\section{China's Taxation Policy on the Financial Innovation Challenge Foresight}

\section{(1)The emphasis on the application of principle of tax regulation}

Due to financial institutions generally has a nature of public service and homogeneity, make it hard for financial products to like industrial products protected by patents and other intellectual property rights, a kind of financial innovation product or system once created, will soon be replicated and low cost for universal service, this will lead to financial innovation has obvious external effects, the external effect on the one hand, financial innovation will lead to increasing the marginal cost of acceleration, on the other hand will make part of the financial innovation product unlimited expansion of scale, and ultimately leads to financial risk. As already mentioned, due to the particularity of financial institutions operating mode and quasi-public products properties of financial services, financial innovation the externality is difficult to solve through the market, and must rely on the government USES the tax measures to restrain, this constitutes the government with the regulation of tax policy of financial innovation theory basis.

\section{(2)Establish and improve the relevant system}

Financial innovation on the wood belongs to the results of the current system, the headstrong, because this is in response to the financial innovation of the government on the impact of tax policy, the government should constantly associated with financial innovation to establish and perfect the system, in order to limit financial innovation in the controllable range, so that half of the financial innovation is conducive to the further development of financial industry and financial markets, without deteriorating financial risks. Specifically speaking, the government shall establish and improve the regulations for the following several aspects: one is based on the economic development needs, adjust the tax system reform, formulation and complicated financial products that meet the needs of a wide range of flexible tax policy; The second is to strengthen the coordination between tax law and related accounting standards, under the condition of may take the legal and the market price adjustment method for derivative financial commodity tax treatment; Three is to strengthen the construction of the relevant financial controls system, through the interaction of financial policy and tax policy to guide the financial innovation is a direction of virtuous cycle.

\section{(3)Strengthen international cooperation}

At present, under the trend of global economic integration, the free flow of capital around the world have made the financial innovation objectively contributed to the financial commodity tax base can flow without borders in the global scope, National tax policy will inevitably lead to international capital tax burden caused by the change of tax arbitrage and so on the financial and tax policies implemented countries taxes adversely affected, and the inconsistency of financial privacy protection and international tax jurisdiction conflicts, which caused by the financial institutions made by a government's tax policy independent alone have been unable to restrain the loss of tax avoidance, tax financial innovation and financial risks, therefore, to actively participate in relevant international cooperation, through international cooperation and global action to fight on tax impact of the financial innovation will become the necessary way of the future tax financial innovation challenge, our government should attach great importance to and actively participate in relevant 
international cooperation, improve the level of the internationalization of China's tax policy.

\section{References}

[1] Shaviro, Daniel N., 2009b. Decoding the U.S. Corporate Tax. Urban Institute Press, Washington, DC.
[2] ]Shiller, RobertJ.,2005. Irrational Exuberance, 2nd Edition. Princeton University Press, Princeton, NJ.

[3] Weder di Mauro, Beatrice, 2010. "Taxing Systemic Risk: Proposal for a Systemic RiskCharge and a Systemic Risk Fund." Working Paper. University of Mainz, Mainz,Germany.

[4] Slemrod, Joel, 2009. "Lessons for Tax Policy in the Great Recession." National TaxJournal 62 (3), 387-397. 